\title{
Microbeam methodologies as powerful tools in manganese hyperaccumulation research: present status and future directions
}

\author{
Denise R. Fernando ${ }^{1 *}$, Alan Marshall ${ }^{2}$, Alan J. M. Baker ${ }^{3}$ and Takafumi Mizuno ${ }^{4}$ \\ ' Department of Botany, La Trobe University, Bundoora, VIC, Australia \\ ${ }^{2}$ Analytical Electron Microscopy Facility, La Trobe University, Bundoora, VIC, Australia \\ ${ }^{3}$ School of Botany, The University of Melbourne, Parkville, VIC, Australia \\ ${ }^{4}$ Graduate School of Bioresources, Mie University, Mie, Japan
}

\section{Edited by:}

Marc Hanikenne, University of

Liège, Belgium

Reviewed by:

Sebastien Thomine, Centre National de la Recherche Scientifique, France Tingsong Liu, The Samuel Roberts Noble Foundation, Inc., USA

\section{*Correspondence:}

Denise R. Fernando, Department of

Botany, La Trobe University,

Biological Sciences 1 Building,

Kingsbury Drive, Bundoora,

VIC 3086, Australia

e-mail:d.fernando@latrobe.edu.au
Microbeam studies over the past decade have garnered unique insight into manganese $(\mathrm{Mn})$ homeostasis in plant species that hyperaccumulate this essential mineral micronutrient. Electron- and/or proton-probe methodologies employed to examine tissue elemental distributions have proven highly effective in illuminating excess foliar $\mathrm{Mn}$ disposal strategies, some apparently unique to $\mathrm{Mn}$ hyperaccumulating plants. When applied to samples prepared with minimal artefacts, these are powerful tools for extracting true 'snapshot' data of living systems. For a range of reasons, Mn hyperaccumulation is particularly suited to in vivo interrogation by this approach. Whilst microbeam investigation of metallophytes is well documented, certain methods originally intended for non-biological samples are now widely applied in biology. This review examines current knowledge about Mn hyperaccumulators with reference to microbeam methodologies, and discusses implications for future research into metal transporters.

\section{Keywords: Mn hyperaccumulator, microbeam analysis, Gossia, Maytenus cunninghamii, Alyxia rubricaulis}

\section{INTRODUCTION}

The intrinsic value of plant hyperaccumulation as a resource for expanding fundamental knowledge is as equally well recognized as are its potential practical benefits (Brooks, 1987; Baker and Brooks, 1989; Baker et al., 1992; Brooks, 1998; Brooks and Robinson, 2000; Chaney et al., 2000; Pollard, 2000; Reeves and Baker, 2000; Lombi et al., 2001; Macnair, 2003; Whiting et al., 2004; Meharg, 2005; Reeves, 2005; Chaney et al., 2007). On a global scale, it is clear that natural systems are increasingly under threat from human activities, with dire predictions for the future survival of many biota. There is thus a pressing need to address habitat conservation of these extraordinary plants and to gain a better understanding of their ecology and evolutionary histories (Pollard, 2000; Reeves and Baker, 2000; Baker and Whiting, 2002; Boyd, 2004; Whiting et al., 2004). Macnair (2003) points out that notwithstanding the potential commercial benefit of hyperaccumulation yet to be realized in any real sense, "the phenomenon is of sufficient intrinsic interest that its investigation is justified without any immediate commercial applications." Whilst economic and environmental factors are major drivers of scientific research in this area, it is likely that accessibility and ease of propagation also influence species selection for study. Ubiquitous herbaceous Ni hyperaccumulators in the Brassicaceae remain the most investigated subgroup to date (Brooks and Radford, 1978; Lee et al., 1978; Gambi et al., 1979; Baker, 1987; Baker and Brooks, 1989; Baker et al., 1992, 2000; Krämer et al., 1997; Brooks, 1998; Nicks and Chambers, 2000; Mengoni et al., 2003; Asemaneh et al., 2006).
The possible benefits of seeking to understand lesser-known hyperaccumulators with restricted distributions and/or more unusual hyperaccumulated elements include: (a) further illuminating hyperaccumulation per se, (b) obtaining novel perspective on the physiological roles of those hyperaccumulated elements essential to plant nutrition, (c) gaining new insights into plant metal specificity and detoxification. Around $22 \mathrm{Mn}$ hyperaccumulators are known worldwide (Table 1), their highly restricted collective distribution centered almost entirely over New Caledonia and Eastern Australia. Reports of two herbaceous Polygonum species described as Mn-hyperaccumulating on $\mathrm{Mn}$ mine sites in China (Wang et al., 2007; Deng et al., 2010) are difficult to access and may require further confirmation. Among well confirmed Mn hyperaccumulators are seven trees and a shrub species from Australia (Bidwell et al., 2002; Fernando et al., 2009), seven woody plants from New Caledonia (Brooks, 1998), a tree and a herb native to China (Xue et al., 2004; Yang et al., 2008), a herb native to the USA (Min et al., 2007; Pollard et al., 2009) and a tree native to Japan (Mizuno et al., 2008). The single Malaysian tree species whilst documented has not been identified below generic level (Proctor et al., 1989). The identities of certain herbaceous Mn hyperaccumulators are yet to be verified taxonomically at the species level, while several trees within the Australian group are listed as threatened due to habitat loss. Given that conservation and research are underpinned by correct identification of hyperaccumulator species, plant taxonomy is integral to the topic. Currently it is an uncommon practice to provide herbarium vouchers on hyperaccumulator plants in 
Table 1 | Current worldwide listing of Mn hyperaccumulators.

\begin{tabular}{ll}
\hline Plant (family) species (citation) & Native country \\
\hline (Araliaceae) & \\
Chengiopanax species formerly in Eleutherococcus & \\
${ }^{*}$ Chengiopanax sciadophylloides (1) & Japan \\
\hline
\end{tabular}

(Apocynaceae)

Alyxia rubricaulis (2)

New Caledonia (NC)

(Celastraceae)

Denhamia species formerly in Maytenus

* Denhamia fournieri (2)

NC

Denhamia cunninghamii (3)

Australia (AU)

(Clusiaceae)

* Garcinia amplexicaulis (2)

NC

(Myrtaceae)

Eugenia sp.1 (2)

Eugenia sp. 2 (4)

NC

Gossia species formerly in Austromyrtus

Gossia bamagensis (3)

* G. bidwillii (5)

G. gonocla (3)

${ }^{*}$ G. fragrantissima (3)

G. lucida (3)

G. sankowsiorum (3)

G. shepherdii (3)

$\mathrm{AU}$

$A U$

AU

AU

AU

AU

$\mathrm{AU}$

(Phytolaccaceae)

* Phytolacca acinosa (6)

China $(\mathrm{CH})$

P. Americana (7)

USA

(Polygonaceae)

Polygonum pubescens (8)

Eurasia (E)

P. hydropiper (9)

E/USA

(Proteaceae)

Beaupreopsis paniculata (10)

NC

Virotia species formerly in Macadamia

Virotia angustifolia (10)

${ }^{*} V$. neurophylla (10)

$\mathrm{NC}$

NC

(Theaceae)

Schima superba (11)

$\mathrm{CH}$

${ }^{*}$ Species examined by microprobe analysis.

References: 1, (Mizuno et al., 2008); 2, (Jaffré, 1977); 3, (Fernando et al., 2009); 4, (Proctor et al., 1989); 5, (Bidwell et al., 2002); 6, (Xue et al., 2004); 7, (Min et al., 2007; Pollard et al., 2009); 8, (Deng et al., 2010); 9, (Wang et al., 2007); 10, (Jaffré, 1979); 11, (Yang et al., 2008).

published research; however, it should be encouraged in order to enable independent verification of species. The majority of $\mathrm{Mn}$ hyperaccumulators are woody plants with sclerophyllous leaves and xerophytic anatomies, traits strongly favorable to retaining leaf-tissue integrity for in vivo microprobe examination.

Plant Mn hyperaccumulation was originally defined by a notional threshold foliar Mn concentration of $10,000 \mu \mathrm{g} \mathrm{g}^{-1}$ dry weight (DW) (Baker et al., 2000). More recently, there has been argument supporting a downward revision (Baker et al., 2000; Fernando et al., 2009). It is widely accepted that Mn predominates in its lowest $(+2)$ oxidation state in planta, and this has been confirmed for several Mn hyperaccumulators, using X-ray absorption near-edge spectroscopy (XANES) (Graham et al., 1988; Fernando et al., 2010). There are multiple physiological functions to which $\mathrm{Mn}$ is essential, primarily photosynthesis and oxidative stress mitigation. Based on crop plants, "normal" nutritional requirements for Mn are met at $\sim 50-800 \mu \mathrm{g} \mathrm{g}^{-1}$ DW even though it is widely tolerated at concentrations above (Graham et al., 1988; Marschner, 2002; Foulds, 2003). This is in marked contrast to other trace metal nutrients. Manganese crop toxicity is a significant problem in certain regions of the world where soils are Mn-enriched and acidic (Heenan and Carter, 1977; TempleSmith and Koen, 1982; Hung et al., 1987; Davis, 1996; González et al., 1998; StClair and Lynch, 2005). The ability of tolerant crop lines to sequester excess $\mathrm{Mn}$, along with $\mathrm{Mn}$ sensitivity in other varieties is not well understood, nor is the observed variation in plant physiological responses. Therefore, Mn hyperaccumulators can be exploited to address these questions given they shine a novel light on Mn nutrition and could potentially yield important new information regarding specific Mn chelators and transporters.

The first reports of Mn hyperaccumulation occurred over 35 years ago upon discovery of the New Caledonian group (Jaffré and Latham, 1974; Jaffré, 1977, 1979). At that time, the now littleused term "hypermangansphores" was introduced to describe Mn hyperaccumulators. In the early 1980s a group of Japanese Mn-accumulating species was the subject of detailed physiological investigation, including microprobe analysis (Memon and Yatazawa, 1980, 1981, 1982, 1984). Over the past decade it has become apparent via in vivo microbeam studies at least that these are somewhat unusual among hyperaccumulators (Fernando et al., 2006a,b, 2008). Between 2002 and 2008, additional Mn hyperaccumulators were discovered in eastern Australia (Bidwell et al., 2002), China (Xue et al., 2004) and Japan (Mizuno et al., 2008), that has now led to recognition of several new species and renewed interest in the phenomenon. To date, the woody species have only been investigated through a series of ecophysiological studies, whereas the two herbaceous Phytolacca (Phytolaccaceae) species have mainly been examined in controlled experiments (Xue et al., 2005; Fernando et al., 2006b; Mizuno et al., 2006; Xu et al., 2006a,b, 2009; Fernando et al., 2007a,b). Unlike their herbaceous metal-hyperaccumulating counterparts, Mnhyperaccumulating trees and shrubs are extremely slow growing and often difficult to propagate.

Pioneering studies on plant hyperaccumulation using widely accessible Ni-, Cd- and Zn-hyperaccumulating herbs provide an invaluable framework for current focus on Mn hyperaccumulation. This has led to: (a) the discovery of several new Mn hyperaccumulators, which has augmented the overall biogeographic knowledge base of hyperaccumulators by providing new perspective on Mn-accumulating taxa analogous to those with already well-established links to other metals (Baker and Brooks, 1989; Baker et al., 1992; Pollard et al., 2000, 2002; Fernando et al., 2009); (b) the discovery that foliar Mn detoxification varies 
specifically in a manner possibly unique to Mn hyperaccumulators (Fernando et al., 2008); (c) indication that the physiological mechanisms associated with excess $\mathrm{Mn}$ uptake and storage in herbaceous Mn hyperaccumulators are similar to those found in herbaceous hyperaccumulators of other metals (Küpper et al., 2000, 2001; Xu et al., 2006a,b); and (d) the pursuit to identify $\mathrm{Mn}$-specific transporters, particularly in woody species where $\mathrm{Mn}$ is compartmentalized in highly localized vacuolar concentrations (T. Mizuno unpublished data).

\section{METAL LOCALIZATION METHODOLOGIES APPLIED TO HYPERACCUMULATORS AND OTHER PLANTS}

Early studies utilizing microbeam techniques to investigate excess Mn sequestration in certain tolerant crop lines established that dermal tissues were primary deposition sites (Blamey et al., 1986; Edwards and Van Steveninck, 1987, 1988). Scanning electron microscopy energy dispersive spectroscopy (SEM/EDS), proton (or particle)-induced X-ray emission energy dispersive spectroscopy (PIXE/EDS) and synchrotron methodologies are by far the most widely used techniques for localizing excess metal deposition within plant tissues. To obtain reliable artifact-free data from in vivo methods such as these, it is imperative that sample preparations effectively immobilize cell metabolic and diffusional processes, thereby avoiding artifactual cell-content removal or relocation of diffusible elements (Marshall, 1980c; Morgan, 1980; Echlin, 1992; Marshall and $\mathrm{Xu}, 1998)$. This subject will be addressed in greater detail below. Other techniques including ${ }^{31} \mathrm{P}$-nuclear magnetic resonance (NMR) (Roby et al., 1988; Quiquampoix et al., 1993a,b) radioactive tracer studies (Lasat et al., 1996), and cell fractionation (González and Lynch, 1999) have also provided useful information regarding metal localization in plants. Mention should also be made of histochemical techniques utilized by Severne (1974) to locate foliar $\mathrm{Ni}$ in situ in a hyperaccumulator using dimethyl glyoxime stain; and by Horiguchi (1987) to localize oxidized $\mathrm{Mn}$ in rice plants by staining with benzidine.

In vivo microprobe investigation has been applied to hyperaccumulating plants to reveal that with the exception of Mn hyperaccumulators, primary sequestration occurs in nonphotosynthetic tissues (Vázquez et al., 1992; Krämer et al., 1997; Küpper et al., 1999, 2000, 2001; Mesjasz-Przybylowicz et al., 2001; Lombi et al., 2002; Ager et al., 2003; Bhatia et al., 2003; Bidwell et al., 2004; Broadhurst et al., 2004; Fernando et al., 2006a,b, 2010; Xu et al., 2006a,b; Smart et al., 2010). For example, Küpper et al. (2000) described the accumulation of $\mathrm{Zn}$ and $\mathrm{Cd}$ in leaves of the hyperaccumulator Arabidopsis halleri (L.) O'Kane and Al-Shehbaz Novon (Brassicaceae), and found the strongest deposition in trichomes, and to a lesser extent in the mesophyll. Bidwell et al. (2004) found Ni predominantly localized in the leaf epidermal vacuoles with some apoplastic localization in the mesophyll tissues of Hybanthus floribundus (Lindley) F. Muell (Violaceae). These and numerous other studies demonstrated that leaf epidermal cell-layers and associated structures such as hairs and trichomes are primary sequestration sites for hyperaccumulated elements, i.e., where highest localized concentrations were detected in vivo. Such findings are consistent with reasoning that, (a) dermal tissues generally have a high apoplastic component, (b) the essentially non-photosynthetic status of dermal tissues renders them suited to storing potentially toxic concentrations of metals that might otherwise disrupt vital physiological processes in the mesophyll, and (c) excess metal storage in the dermal layers may contribute to chemical defence against animal and/or insect herbivory. In contrast to all other hyperaccumulators examined to date, Mn hyperaccumulators exhibit a distinct variety of primary detoxification strategies, i.e., in photosynthetic tissues, in non-photosynthetic tissues, and simultaneously across all tissue types (Fernando et al., 2008). Currently there is no clear explanation for this observation. It has been argued that the highly vacuolated xerophytic leaf anatomies of woody Mn hyperaccumulators along with the essential role of $\mathrm{Mn}$ in photosynthesis might be associated with its concentration in photosynthetic cells. Most recently however, PIXE/EDS localization studies showed that primary foliar-metal sequestration in a Co-, Ni- and $\mathrm{Zn}$-accumulating $\mathrm{Mn}$ hyperaccumulator tree Gossia fragrantissima (F. Muell. ex Benth.) N. Snow and Guymer (Myrtaceae) occurred in photosynthetic cells for Mn, $\mathrm{Ni}$ and $\mathrm{Co}$; and in non-photosynthetic cells for Zn (Fernando et al., 2013). In further illuminating primary Mn-sequestration in the leaf mesophyll cells of a woody Mn hyperaccumulator, these latest findings indicate involvement of tonoplastal metal transporters not exclusive to $\mathrm{Mn}$ since in this species at least, $\mathrm{Ni}$ and $\mathrm{Co}$ were in addition to $\mathrm{Mn}$, primarily located in photosynthetically important cells.

\section{LOCALIZATION STUDIES ON Mn HYPERACCUMULATORS}

As discussed earlier, original in vivo examination of foliar $\mathrm{Mn}$ microdistribution was performed on $\mathrm{Mn}$ accumulators from Japan, including Chengiopanax sciadophylloides (Franch. and Sav.) C. B. Shang and J. Y. Huang (Araliaceae) now identified as a "true" Mn hyperaccumulator (Mizuno et al., 2008). However, these samples were prepared by freezing leaf material directly in liquid nitrogen, an approach now regarded as unreliable in achieving adequate cryo fixation at the cellular level (see Echlin, 1992). About 25 years later, Gossia bidwillii (Benth.) N. Snow and Guymer (Myrtaceae), a Mn-hyperaccumulating Australian rainforest tree; and $P$. acinosa Roxb, a herbaceous Chinese Mn hyperaccumulator were examined in separate Mn localization studies utilizing cryo-SEM/EDS and synchrotron radiation X-ray fluorescence spectroscopy (SRXRF), respectively, (Fernando et al., 2006b; Xu et al., 2006a,b). Whilst the latter authors showed foliar Mn to be most strongly deposited in the upper epidermis of $P$. acinosa, they also conceded that their sample preparation might have been a confounding factor. Methodology lacking the essential initial step of immediate rapid-freezing of leaf tissue will likely yield unreliable data as a result of artifactual movement of cell solutes and water during subsequent sample processing and/or microbeam analysis. Studies on woody Mn hyperaccumulators utilized appropriate sample fixation that retained cellular content in close representation of the in vivo status. Leaf anatomical features of these species typically include substantial cuticles, particularly for the New Caledonian group; multiple layers of large palisade mesophyll cells, and an overall distinct lack of intercellular spaces throughout (Fernando 
et al., 2006a,b, 2007b, 2008, 2012). These leaves are dermally fortified around closely packed and highly vacuolated cells that account for an overall high vacoular component of the total leaf volume. After field sampling, it is often necessary to maintain material in cool humid packaging over transit periods of least $24 \mathrm{~h}$ between remote field collection sites and laboratories where they are immediately cryo-fixed prior to storage or any subsequent processing. Their physical robustness combined with highly localized cellular Mn concentrations that fall well within the detection limits of widely used microprobe methodologies render leaf samples of these woody Mn hyperaccumulators ideal for in vivo microprobe localization studies on bulk specimens. Their characteristic leaf sclerophylly on the other hand poses challenges to sample infiltration steps essential to ultrastructural examination by transmission electron microscopy (TEM), and/or analysis by scanning transmission electron microscopy (STEM) EDS.

\section{LEAF SAMPLE PREPARATION FOR In vivo MICROPROBE EXAMINATION OF HYPERACCUMULATORS}

Appropriate sample preparation is mandatory to obtaining reliable in vivo microprobe analytical data from biological material. Reference to "sample" here should be taken to mean leaf tissues. Sample preparation methodology can determine the degree of anatomical resolution achievable by SEM, as can instrumentation. The latter also governs the limits of analytical resolution and sensitivity, for example, factors such as operating conditions, the choice of incident microbeam, detector and analyzer. There is ample evidence that biological sample preparation for in vivo microprobe analysis requires initial rapid cryo-fixation to immobilize metabolic processes and prevent delocalization of diffusible elements (e.g., Echlin et al., 1980; Marshall, 1980a; Echlin, 1992; Marshall and Xu, 1998). Plunging samples directly into liquid nitrogen, while commonly used, does not achieve rapid cryo-fixation since the sample at room temperature upon contact with liquid nitrogen forms a self-enveloping "nitrogen gas vapor cloud," which has an insulating effect not conducive to rapid freezing. This is known as the "Leidenfrost effect". Plunge- and metal-mirror contact-freezing methods can be employed to achieve rapid sample vitrification free of ice crystals, which can lead to cell content relocation and membrane rupture. It is desirable to maintain as small a sample size as possible to achieve artifact-free vitrification. Following appropriate cryo-fixation, samples can then be used for analysis after surface polishing or sectioning by cryo-ultramicrotomy. Bulk frozen tissue is cryo-planed to optimize X-ray collection by the detector since a rough sample surface causes irregular absorption, which can then produce inconsistent analytical data. Planing is done cross-sectionally to enable examination of the in vivo spatial distribution patterns of elements including $\mathrm{Mn}$ through the leaf tissue. Samples can also be processed from a frozen cryo-fixed state to a dry state, depending on the constraints and requirements of an investigation. Whether wet or dry, samples are commonly surface-coated with a fine conductive layer of metal or carbon to avoid charge accumulation from the incident beam provided it does not confound analytical data.
Melting nitrogen, liquid propane and isopentane have previously been used to cryo-fix Mn hyperaccumulator samples for wet and dry sample preparations examined by qualitative and quantitative electron and proton probe studies (Fernando et al., 2006a,b, 2013). Whether applied to wet or dry samples, quantitative approaches are more time consuming and expensive. Qualitative X-ray mapping used on freeze-dried bulk tissue cut open to expose a clean cross-sectional surface has to date been best exploited to locate primary $\mathrm{Mn}$ sinks in Mn hyperaccumulator samples (Figure 1) (Fernando et al., 2006a, 2007b, 2008). Again, it is noteworthy that the sclerophyllous nature of these leaves is a distinct advantage when hand-cutting freeze dried tissue. This is a relatively straightforward yet effective approach given that Mn hyperaccumulators harbour highly localized foliar $\mathrm{Mn}$. If necessary, these findings can then be followed up by quantitative techniques to characterize $\mathrm{Mn}$ sinks in greater detail, using additional samples prepared appropriately. For example, SEM/EDS measurement of vacuolar elemental concentrations within individual cells can be carried out on frozen hydrated cryoplaned samples treated to improve anatomical clarity by superficial surface-sublimation and metal coating (Figure 2) (Fernando et al., 2006b, 2012, 2013). A preparation such as this offers minimal disruption to metabolic processes, and is the closest achievable representation of the true in vivo state for a fixed sample, provided it was correctly cryo-fixed at the outset. Among the disadvantages of this approach however, is that the sample water content has a "diluting" effect that renders cellular elements less detectable than in correspondingly dry tissue, although $\mathrm{Mn}$ is generally localized in sufficiently high concentrations to be easily detected even in fully hydrated tissue. Here, Figures 1, 2 are presented side-by-side to reinforce the point that leaves of woody Mn hyperaccumulators by virtue of their physical robustness, leaf anatomy combined with extraordinary foliar Mn concentrations, are almost uniquely equally well suited to both wet and dry sample preparation for in vivo analyses-be they qualitative or quantitative. Hydrated samples are advantageous in that the analytical resolution is higher than in freeze-dried samples since it is partially determined by sample depth. However, high incident beam energies can lead to beam damage on the sample

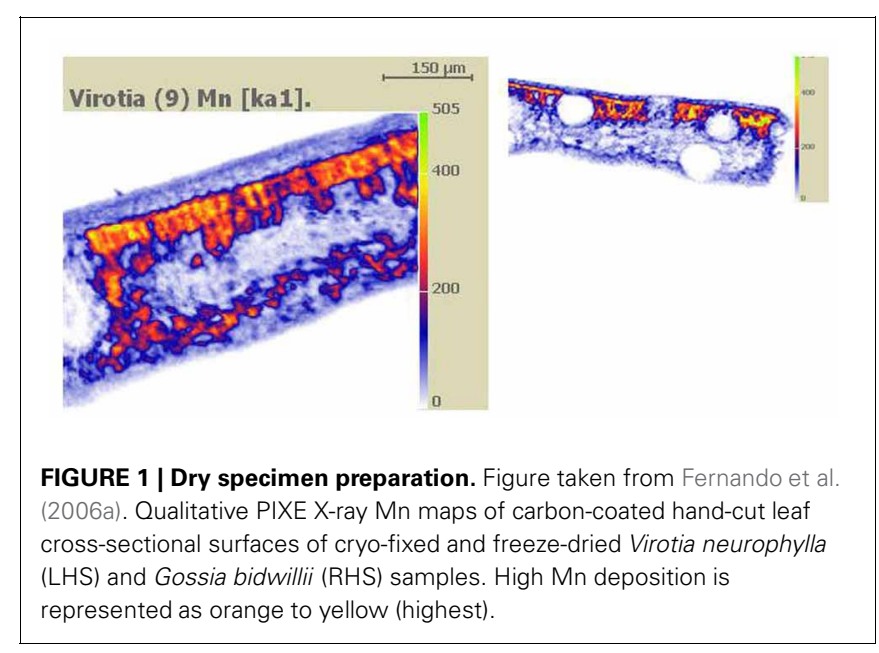




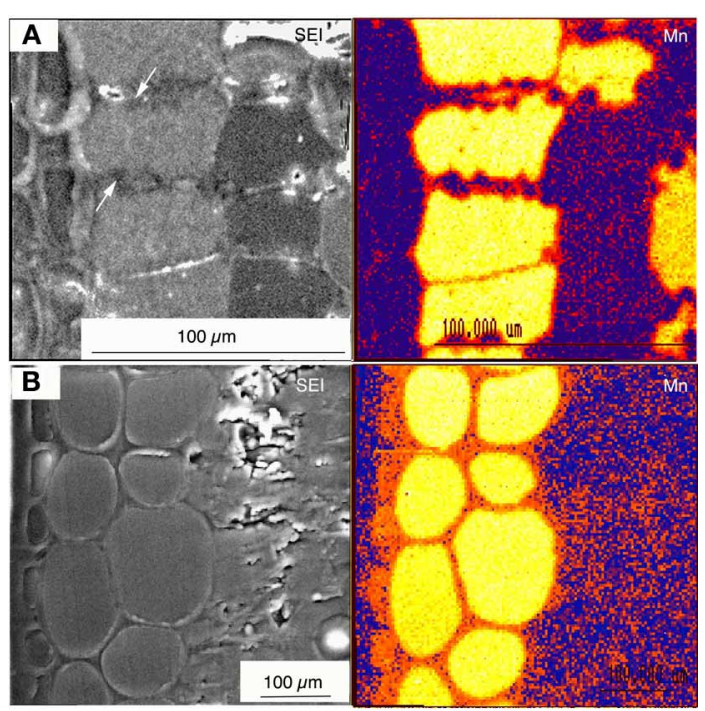

FIGURE 2 | Wet specimen preparation. Figure taken from Fernando et al. (2012). Cryo-fixed frozen hydrated and planed leaf cross sectional surfaces of Virotia neurophylla (A) and Maytenus fournieri (B) lightly surface sublimed and Al-coated. LHS panels show cryo-SEM images (15 kV); and RHS panels show corresponding quantitative X-ray maps with localized vacuolar $\mathrm{Mn}$ highlighted in orange to yellow (highest).

(Marshall, 1980c). Küpper et al. (1999, 2000, 2001) and Robinson et al. (2003) have similarly employed cryo-SEM/EDS on cryofixed frozen samples to examine $\mathrm{Ni}, \mathrm{Cd}$, and $\mathrm{Zn}$ localization in herbaceous hyperaccumulators, and achieved subcellular spatial resolution of metal distribution in hydrated tissues. Freeze drying cryo-fixed material on the other hand, while elevating analytical detection limits, leads to further loss of analytical resolution when the water matrix is removed from cells. Analysis of sections using STEM enables examination of tissue ultrastructure with cell contents intact. This is achieved by anhydrous freeze-substitution as used by Bidwell et al. (2004) to quantify foliar Ni sequestration in vivo in a herbaceous $\mathrm{Ni}$ hyperaccumulator. In an initial process of cryo-substitution, tissue-water as ice is slowly replaced with a non-polar solvent, subsequently followed by resin infiltration (Pallaghy, 1973; Marshall, 1980b). Thick sections (1-2 $\mu \mathrm{m})$ can then be used for energy dispersive analysis in STEM. It is unlike TEM sample preparations routinely used for anatomical/ultrastructural studies, in which cellular ions are washed out in polar solvents such as acetone and ethanol (Morgan, 1980). The authors' previous experience in attempting to infiltrate sclerophyllous leaf tissues of woody Mn hyperaccumulators for TEM studies were unsuccessful due to the apparent impermeabilty of samples. Major considerations when preparing woody hyperaccumulator plant material for in vivo microprobe analysis is broadly summarized in Figure 3, however, caution needs to be exercized when interpreting these steps for other material and species. For example, "soft" herbaceous plant material while more permeable to fixatives, requires far more rapid handling between collection sites and laboratory, and are considerably less suited to dry hand-sectioning.

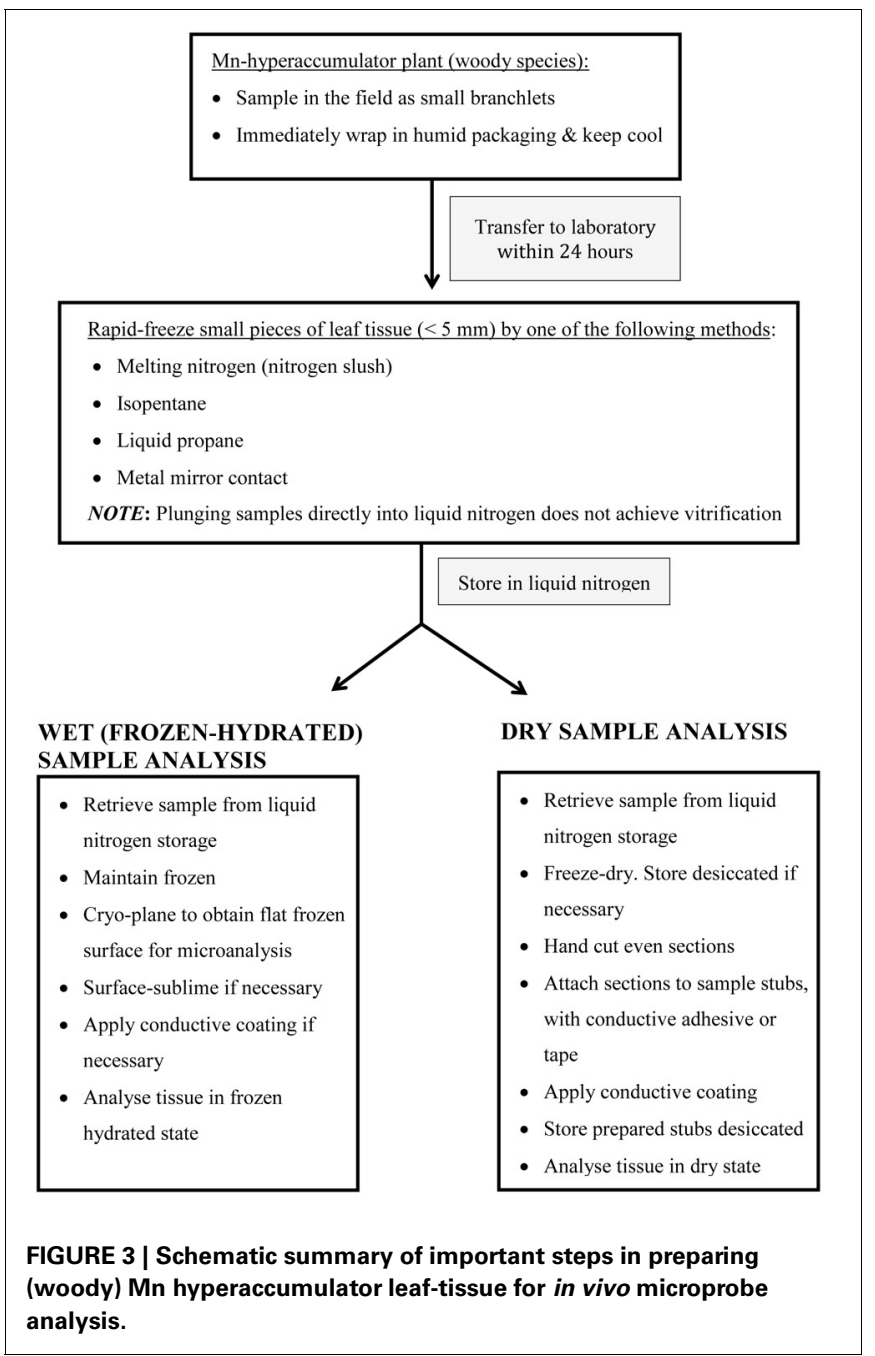

\section{Mn TRANSPORTER STUDIES AND FUTURE DIRECTIONS}

The accumulation of shoot tissue Mn concentrations significantly above normal plant nutritional requirements is not an uncommon observation that raises questions about transporters associated with foliar Mn compartmentalization and specificity at the root-soil interface. Plants that hyperaccumulate Mn can be viewed as exceptional in this regard. There has been little success in the search for Mn transporters responsible for Mn acquisition by model plants. As reviewed by Pittman (2005), certain classes of divalent-metal transporters such as the ZIP (ZRT1/IRT1-related protein) and NRAMP (natural resistanceassociated macrophage protein) appear to be implicated in $\mathrm{Mn}$ transport. Recently, a group of NRAMP transporters including OsNramp5 in rice (Ishimaru et al., 2012; Sasaki et al., 2012), and AtNramp1 in Arabidopsis thaliana (Cailliatte et al., 2010) were found to be involved in Mn uptake at the root surface. The NRAMP group is recognized as being associated with heavy metal transport and possibly contributing to plant adaptation to metal homeostasis (Thomine et al., 2000). In certain instances they are more highly expressed in metal-hyperaccumulating plants than in models such as A. thaliana (Weber et al., 2004; 
Oomen et al., 2009). This suggests that NRAMP transporters are important to metal hyperaccumulation either at the uptake level, root to shoot translocation, or detoxification via vacuolar compartmentation. Similarly, the ZIP transporters are known to be highly expressed in metal hyperaccumulators. However, since neither NRAMP nor ZIP transporters appear to be highly expressed in Mn hyperaccumulators, there is little evidence of their involvement in Mn-hyperaccumulative uptake and/or accumulation (T. Mizuno, pers. comm.). Delhaize et al. (2003) identified ShMTP8 as a vacuolar transporter responsible for Mn-accumulative tolerance in Stylosanthes hamata (Fabaceae), and also described AtMTP11 as a Mn transporter in prevacuolar compartments of Arabidopsis (2007). Peiter et al. (2007) found that the Mn transporter MTP11 was associated with Golgi bodies in Arabidopsis mtp 11 mutants exhibiting an enhanced ability to accumulate Mn in their shoots and roots.

In vivo microprobe localization methodologies have expanded knowledge about the compartmentalization of excess foliar
$\mathrm{Mn}$ in hyperaccumulators by revealing remarkable tonoplastal specificity within certain cell types, particularly the palisade mesophyll (Fernando et al., 2006a,b, 2012). These findings provide basis for future genetic studies to identify drivers of Mn hyperaccumulation, which could ultimately contribute to discussion on plant Mn accumulation in the context of Mn crop toxicity. Discovery that foliar Mn is variously co-localized with excess $\mathrm{Zn}, \mathrm{Co}$, and $\mathrm{Ni}$ in different palisade cell-layers of a $\mathrm{Mn}$ hyperaccumulator provides further insight into metal transporters (Fernando et al., 2013). Currently there is no published research on the genetic basis of $\mathrm{Mn}$ hyperaccumulation. With a single exception, Mn transporter studies in yeast, plant models (Delhaize et al., 2003, 2007; Mizuno et al., 2005; Pittman, 2005), and the Mn hyperaccumulator C. sciadophylloides ( $\mathrm{T}$. Mizuno, pers. comm.) have largely been unsuccessful in characterizing the molecular basis of detoxification mechanisms associated with excess foliar Mn sequestration in Mn-accumulating plants.

\section{REFERENCES}

Ager, F. J., Ynsa, M. D., DominguezSolis, J. R., Lopez-Martin, M. C., Goter, C., and Romero, L. C. (2003). Nuclear micro-probe analysis of Arabidopsis thaliana leaves. Nucl. Instrum. Methods Phys. Res. B 210, 401-406. doi: 10.1016/S0168583X(03)01046-2

Asemaneh, T., Ghaderian, S. M., Crawford, S. A., Marshall, A. T., and Baker, A. J. M. (2006). Cellular and subcellular compartmentation of $\mathrm{Ni}$ in the Eurasian serpentine plants Alyssum bracteatum, Alyssum murale, (Brassicaceae) and Cleome heratensis (Capparaceae). Planta 225, 193-202. doi: 10.1007/s00425-006-0340-y

Baker, A. J. M. (1987). Metal tolerance. New Phytol. 106, 93-111. doi: 10.1111/j.14698137.1987.tb04685.x

Baker, A. J. M., and Brooks, R. R. (1989). Terrestrial higher plants which hyperaccumulate metallic elements-a review of their distribution, ecology and phytochemistry. Biorecovery 1, 81-126.

Baker, A. J. M., McGrath, S. P., Reeves, R. D., and Smith, J. A. C. (2000). "Metal hyperaccumulator plants: a review of the ecology and physiology of a biological resource for phytoremediation of metal-polluted soils," in Phytoremediation of Contaminated Soil and Water, eds N. Terry and G. Bañuelos (Boca Raton, FL: CRC Press LLC), 85-108.

Baker, A. J. M., Proctor, J., and Reeves, R. D. (1992). The Vegetation of Ultramafic (Serpentine) Soils. Andover: Intercept.
Baker, A. J. M., and Whiting, S. N. (2002). In search of the Holy Grail - a further step in understanding metal hyperaccumulation. New Phytol. 155, 1-7. doi: 10.1046/j.14698137.2002.00449_1.x

Bhatia, N. P., Orlic, I., Ashwath, N., Baker, A. J. M., and Walsh, K. (2003). Elemental mapping using PIXE shows the main pathway of nickel movement is principally symplastic within the fruit of the hyperaccumulator Stackhousii tyronii. New Phytol. 160, 479-488. doi: 10.1046/j.14698137.2003.00912.x

Bidwell, S. D., Crawford, S. A., Woodrow, I. E., Sommer-Knusden, J., and Marshall, A. T. (2004). Sub-cellular localization of $\mathrm{Ni}$ in the hyperaccumulator Hybanthus floribundus (Lindley) F. Muell. Plant Cell Environ. 27, 705-716. doi: 10.1111/j.0016-8025.2003.01170.x

Bidwell, S. D., Woodrow, I. E., Batianoff, G. N., and Sommer-Knusden, J. (2002). Hyperaccumulation of manganese in the rainforest tree Austromyrtus bidwillii (Myrtaceae) from Queensland, Australia. Funct. Plant Biol. 29, 899-905. doi: 10.1071/PP01192

Blamey, F. P. C., Joyce, D. C., Edwards, D. G., and Asher, C. J. (1986). Role of trichomes in sunflower tolerance to manganese toxicity. Plant Soil 91, 171-180. doi: 10.1007/BF02181785

Boyd, R. S. (2004). Ecology of metal hyperaccumulation. New Phytol. 162, 563-567. doi: 10.1111/j.14698137.2004.01079.x
Broadhurst, C. L., Chaney, R. L., Angle, J. S., Maucel, T. K., Erbe, E. F., and Murphy, C. A. (2004). Simultaneous hyperaccumulation of nickel, manganese and calcium in Alyssum leaf trichomes. Environ. Sci. Technol. 38, 5797-5802. doi: 10.1021/es0493796

Brooks, R. R. (1987). Serpentine and its Vegetation: A Multidisciplinary Approach. Portland, OR: Dioscorides Press.

Brooks, R. R. (1998). Plants that Hyperaccumulate Heavy Metals. Oxon; New York: CAB International.

Brooks, R. R., and Radford, C. C. (1978). Nickel accumulation by European species of the genus Alyssum. Proc. $R$. Soc. Lond. B 200, 217-224. doi: 10.1098/rspb.1978.0016

Brooks, R. R., and Robinson, B. H. (2000). "The potential use of hyperaccumulators and other plants for phytomining," in Plants that Hyperaccumulate Heavy Metals, ed R. R. Brooks (Oxon; New York: CAB International), 327-356.

Cailliatte, R., Schikora, A., Briat, J.-F., Mari, S., and Curie, C. (2010). High-affinity manganese uptake by the metal transporter NRAMP1 is essential for Arabidopsis growth in low manganese conditions. Plant Cell 22, 904-917. doi: 10.1105/tpc.109.073023

Chaney, R. L., Angle, J. S., Broadhurst, C. L., Peters, C. A., Tappero, R. V., and Sparks, D. L. (2007). Improved understanding of hyperaccumulation yields commercial phytoextraction and phytomining technologies. J. Environ. Qual. 36, 1429-1443. doi: $10.2134 /$ jeq2006.0514
Chaney, R. L., Li, Y. M., Brown, S. L., Homer, F. A., Malik, M., Angle, J. S., et al. (2000). "Improving metal hyperaccumulator wild plants to develop commercial phytoextraction systems: approaches and progress," in Phytoremediation of Contaminated Soil and Water, eds N. Terry and G. Bañuelos (Boca Raton, Florida: CRC Press LLC), 129-158.

Davis, J. G. (1996). Soil $\mathrm{pH}$ and magnesium effects on manganese toxicity in peanuts. J. Plant Nutr. 19, 535-550. doi: 10.1080/01904169609365141

Delhaize, E., Gruber, B., Pittman, J. K., White, R. G., Leung, H., Miao, Y., et al. (2007). A role for the AtMTP11 gene of Arabidopsis in manganese transport and tolerance. Plant $J$. 51, 198-210. doi: 10.1111/j.1365313X.2007.03138.x

Delhaize, E., Katoka, T., Hebb, D. M., White, R. G., and Ryan, P. R. (2003). Genes encoding proteins of the cation diffusion facilitator family that confer manganese tolerance. Plant Cell 15, 1131-1142. doi 10.1105/tpc.009134

Deng, H., Li, M. S., and Chen, Y. X. (2010). Accumulating characteristics of manganese by Polygonum pubescens Blume. J. Guangxi Norm. Univ. Nat. Sci. Ed. 28, 58-62.

Echlin, P. (1992). Low-Temperature Microscopy and Analysis. London: Plenum Press. doi: 10.1007/978-14899-2302-8

Echlin, P., Lai, C. E., Haynes, T. L., and Hook, G. (1980). Elemental analysis of frozen-hydrated differentiating phloem parenchyma in roots of Lemna minor L. Scan. Electron Microsc. II, 383-394. 
Edwards, L. B., and Van Steveninck, R. F. M. (1987). "Quantitative determination of manganese and silicon in freeze-fractured plant material," in Proceedings of the Ninth Australian Symposium on Analytical Chemistry, (Sydney: Royal Australian Chemical Institute), 351-354.

Edwards, L. B., and Van Steveninck, R. F. M. (1988). "A quantitative microprobe study of manganese tolerance in two crops," in International Symposium on Manganese in Soils and Plants, eds M. J. Webb RON, R. D. Graham, and R. J. Hannam (Adelaide), 37-39.

Fernando, D. R., Bakkaus, E. J., Perrier, N., Baker, A. J. M., Woodrow, I. E., Batianoff, G. N., et al. (2006a). Manganese accumulation in the leaf mesophyll of four tree species: a PIXE/EDAX localization study. New Phytol. 171, 751-758. doi: 10.1111/j.14698137.2006.01783.x

Fernando, D. R., Batianoff, G. N., Baker, A. J., and Woodrow, I. E. (2006b). In vivo localisation of manganese in the hyperaccumulator Gossia bidwillii (Benth.) N. Snow and Guymer (Myrtaceae) by cryoSEM/EDAX. Plant Cell Environ. 29, 1012-1020. doi: 10.1111/j.13653040.2006.01498.x

Fernando, D. R., Guymer, G., Reeves, R. D., Woodrow, I. E., Baker, A. J., and Batianoff, G. N. (2009). Foliar Mn accumulation in eastern Australian herbarium specimens: prospecting for 'new' Mn hyperaccumulators and its potential application in taxonomy. Ann. Bot. 103, 931-939. doi: 10.1093/aob/mcp013

Fernando, D. R., Marshall, A. T., Forster, P. I., Hoebee, S. E., and Siegele, R. (2013). Multiple metal accumulation within a mangnaesespecific genus. Am. J. Bot. 100, 690-700. doi: 10.3732/ajb.1200545

Fernando, D. R., Marshall, A. T., Gouget, B., Carrière, M., Collins, R. N., Woodrow, I. E., et al. (2008). Novel Pattern of foliar metal distribution in a manganese hyperaccumulator. Funct. Plant Biol. 35, 193-200. doi: 10.1071/FP07272

Fernando, D. R., Mizuno, T., Woodrow, I. E., Baker, A. J. M., and Collins, R. N. (2010). Characterization of foliar manganese (Mn) in $\mathrm{Mn}$ (hyper)accumulators using X-ray absorption spectroscopy. New Phytol. 188, 1014-1027. doi: 10.1111/j.14698137.2010.03431.x

Fernando, D. R., Woodrow, I. E., Baker, A. J. M., and Marshall, A. T. (2012). Plant homeostasis of foliar manganese sinks: specific variation in hyperaccumulators. Planta 236, 1459-1470. doi: 10.1007/s00425-012-1699-6

Fernando, D. R., Woodrow, I. E., Bakkaus, E. J., Collins, R. N., Baker, A. J. M., and Batianoff, G. N. (2007a). Variability of $\mathrm{Mn}$ hyperaccumulation in the Australian rainforest tree Gossia bidwillii (Myrtaceae). Plant Soil 293, 145-152. doi: 10.1007/s11104-007-9269-6

Fernando, D. R., Woodrow, I. E., Jaffré, T., Dumontet, V., Marshall, A. T., and Baker, A. J. M. (2007b). Foliar $\mathrm{Mn}$ accumulation by Maytenus founieri (Celastraceae) in its native New Caledonian habitats: populational variation and localisation by X-ray microanalysis. New Phytol. 177, 178-185.

Foulds, W. (2003). Nutrient concentrations of foliage and soil in south-western Australia. New Phytol. 125, 529-546. doi: 10.1111/j.14698137.1993.tb03901.x

Gambi, O. V., Pancaro, L., and Gabbrielli, R. (1979). Investigations on a nickel accumulating plant: Alyssum bertolonii Desv. II. phosphorous, potassium, ron and trace element content and distribution during growth. Atti della Societa Toscana di Scienze Naturali Ser. B 86, 317-329.

González, A., and Lynch, J. (1999). Subcellular and tissue compartmentation in bean leaves under Mn toxicity stress. Aust. J. Plant Physiol. 26, 811-822. doi: 10.1071/PP99030

González, A., Steffen, K. L., and Lynch, J. P. (1998). Light and excess manganese. Plant Physiol. 118, 493-504.

Graham, R. D., Hannam, R. J., and Uren, N. C. (1988). "Manganese in soils and plants," in International Symposium on Manganese in Soils and Plants, eds R. D. Graham, R. J. Hannam, and N. C. Uren (Glen Osmond, South Australia: Kluwer Academic Press). doi: 10.1007/97894-009-2817-6

Heenan, D. P., and Carter, O. G. (1977). Influence of temperature on the expression of manganese toxicity by two soybean varieties. Plant Soil 47, 219-227. doi: 10.1007/BF00010381

Horiguchi, T. (1987). Mechanism of manganese toxicity and tolerance of plants II. Deposition of oxidized manganese in plant tissues. Soil Sci. Plant Nutr. 33, 595-606. doi: 10.1080/ 00380768.1987.10557608

Hung, T. V., Handson, P. D., Amenta, V. C., Kyle, W. S., and Yu, R.
S. (1987). Content and distribution of manganese in lupin seed grown in Victoria and in lupin flour, spray-dried powder and protein isolate prepared from the seeds. J. Sci. Food Agric. 41, 131-139. doi: $10.1002 /$ jsfa.2740410206

Ishimaru, Y., Takahashi, R., Bashir, K., Shimo, H., Senoura, T., Sugimoto, $\mathrm{K}$., et al. (2012). Characterizing the role of rice NRAMP5 in manganese, iron and cadmium transport. Sci. Rep. 2, 286. doi: 10.1038/srep00286

Jaffré, T. (1977). Accumulation du manganèse par des especes associées aux terrains ultrabasiques de Nouvelle-Calédonie. Compt. Rend. Acad. Sci. (Paris). Sér. D 284, 1573-1575.

Jaffré, T. (1979). Accumulation du manganèse par les Proteacées de Nouvelle-Calédonie. Compt. Rend. Acad. Sci. (Paris). Sér. D 289, 425-428.

Jaffré, T., and Latham, M. (1974). Contribution a l'étude des relations sol-végétation sur un massif des roches ultrabasiques de la cote ouest de la Nouvelle-Calédonie: Le Boulinda. Adansonia 14, 311-336.

Krämer, U., Grime, G. W., Smith, J. A. C., Hawes, C. R., and Baker, A. J. M. (1997). Micro-PIXE as a technique for studying nickel localization in leaves of the hyperaccumulator Alyssum lesbiacum. Nuclear Instr. Meth. Phys. Res. 130, 346-350. doi: 10.1016/S0168583X(97)00368-6

Küpper, H., Lombi, E., Zhao, F., and McGrath, S. P. (2000). Cellular compartmentation of cadmium and zinc in relation to other elements in the hyperaccumulator Arabidopsis halleri. Planta 212, 75-84. doi: $10.1007 / \mathrm{s} 004250000366$

Küpper, H., Lombi, E., Zhao, F., Wieshammer, G., and McGrath, S. P. (2001). Cellular compartmentation of nickel in the hyperaccumulators Alyssum lesbiacum, Alyssum bertolonii and Thlaspi goesingense. J. Exp. Bot. 52, 2291-2300. doi: 10.1093/jexbot/52.365.2291

Küpper, H., Zhao, F., and McGrath, S. (1999). Cellular compartmentation of zinc in leaves of the hyperaccumulator Thlaspi caerulescens. Plant Physiol. 119, 305-312. doi: 10.1104/pp.119.1.305

Lasat, M. M., Baker, A. J. M., and Kochian, L. V. (1996). Physiological characterization of root $\mathrm{Zn} 2+$ absorption and translocation to shoots in Zn hyperaccumulator and nonaccumulator species of Thlaspi. Plant Physiol. 112, 1715-1722.
Lee, J., Reeves, R. D., Brooks, R. R., and Jaffré, T. (1978). The relation between nickel and citric acid in some nickel-accumulating plants. Phytochemistry 17, 1033-1035. doi: 10.1016/S0031-9422(00)94274-2

Lombi, E., Zhao, F. J., Dunham, S. J., and McGrath, S. P. (2001). Phytoremediation of heavy metal-contaminated soils: natural hyperaccumulation versus chemically enhanced phytoextraction. J. Environ. Q. 30, 1919-1926. doi: $10.2134 /$ jeq2001.1919

Lombi, E., Zhao, F. J., Fuhrmann, M., Ma, L. Q., and McGrath, S. P. (2002). Arsenic distribuition and speciation in the fronds of the hyperaccumulator Pteris vittata. New Phytol. 156, 195-203. doi: 10.1046/j.1469-8137.2002.00512.x

Macnair, M. (2003). The hyperaccumulation of metals by plants. Adv. Bot. Res. 40, 63-105. doi: 10.1016/S00652296(05)40002-6

Marschner, H. (2002). Mineral Nutrition of Higher Plants. London: Academic Press.

Marshall, A. T. (1980a). Quantitative $\mathrm{X}$-ray microanalysis of frozenhydrated bulk biological specimens. Scan. Electron Microsc. II, 335-348.

Marshall, A. T. (1980b). Freezesubstitution as a preparation technique for biological X-ray microanalysis. Scan. Electron Microsc. II, 395-408.

Marshall, A. T. (1980c). "Frozenhydrated bulk specimens," in X-ray Microanalysis in Biology, ed M. A. Hayat (London: Macmillan), 167-196.

Marshall, A. T., and Xu, W. (1998). Quantitative elemental $\mathrm{x}$-ray imaging of frozen-hydrated biological samples. J. Microsc. 190, 305-316. doi: 10.1046/j.13652818.1998.00313.x

Meharg, A. A. (2005). Mechanisms of plant resistance to metal and metalloid Ions and potential biotechnological applications. Plant Soil 274, 163-174. doi: 10.1007/s11104-0040262-z

Memon, A. R., and Yatazawa, M. (1980). Distribution of manganese in leaf tissues of manganese accumulator: Acanthopanax sciadophylliodes as revealed by electronprobe X-ray microanalyzer. J. Plant Nutr. 2, 457-476. doi: $10.1080 / 01904168009362790$

Memon, A. R., and Yatazawa, M. (1981). Microdistribution of aluminium and manganese in the tea leaf tissues as revealed by X-ray microanalyzer. Commun. Soil 
Sci. Plant Anal. 12, 441-452. doi: 10.1080/00103628109367164

Memon, A. R., and Yatazawa, M. (1982). Chemical nature of manganese in the leaves of manganese accumulator plants. Soil Sci. Plant Nutr. 28, 401-412. doi: 10.1080/ 00380768.1982.10433655

Memon, A. R., and Yatazawa, M. (1984). Nature of manganese complexes in manganese accumulator plant Acanthopanax sciadophylloides. J. Plant Nutr. 7, 961-974. doi: 10. 1080/01904168409363257

Mengoni, A., Baker, A. J. M., Bazzicalupo, M., Reeves, R. D., Adigüzel, N., Chianni, E., et al. (2003). Evolutionary dynamics of nickel hyperaccumulation in Alyssum revealed by ITS nrDNA analysis. New Phytol. 159, 691-699. doi: 10.1046/j.14698137.2003.00837.x

Mesjasz-Przybylowicz, J., Przybylowicz, W. J., and Pineda, C. A. (2001). Nuclear microprobe studies of elemental distribution in apical leaves of the $\mathrm{Ni}$ hyperaccumulator Berkheya coddii. S. Afr. J. Sci. 97, 591-593.

Min, Y., Boqing, T., Meizhen, T., and Aoyama, I. (2007). Accumulation and uptake of manganese in a hyperaccumulator Phytolacca americana. Minerals Eng. 20, 188-190. doi: 10.1016/ j.mineng.2006.06.003

Mizuno, T., Asahina, R., Hosono, A., Tanaka, A., Senoo, K., and Obata, H. (2008). Age-dependent manganese hyperaccumulation in Chengiopanax sciadophylloides (Araliaceae). J. Plant Nutr. 31, 1811-1819. doi: 10.1080/01904160802325396

Mizuno, T., Hirano, K., Hosono, A., Kato, S., and Obata, H. (2006). Continual pH lowering and manganese dioxide solubilization in the rhizosphere of the Mn-hyperaccumulator plant Chengiopanax sciadophylloides. Soil Sci. Plant Nutr. 52, 726-733. doi: 10.1111/j. 1747-0765.2006.00099.x

Mizuno, T., Usui, K., Horie, K., Nosaka, S., Mizuno, N., and Obata, H. (2005). Cloning of three ZIP/Nramp transporter genes from a Ni hyperaccumulator plant Thlaspi japonicum and their Ni2+transport abilities. Plant Physiol. Biochem. 43, 793-801. doi: 10.1016/j.plaphy.2005.07.006

Morgan, A. J. (1980). "Preparation of specimens: changes in chemical integrity," in X-ray Microanalysis in
Biology, ed M. A. Hayat (London: Macmillan), 65-166.

Nicks, L. J., and Chambers, M. F. (2000). "A pioneering study of the potential of phytomining for nickel," in Plants that Hyperaccumulate Heavy Metals, ed R. R. Brooks (Oxon; New York: CAB International), 313-325.

Oomen, R. J., Wu, J., Lelièvre, F., Blanchet, S., Richaud, P., Barbier-Brygoo, H., et al. (2009). Functional characterization of NRAMP3 and NRAMP4 from the metal hyperaccumulator Thlaspi caerulescens. New Phytol. 181, 637-650. doi: 10.1111/j.14698137.2008.02694.x

Pallaghy, C. K. (1973). Electron probe microanalysis of potassium and chloride in freeze-substututed leaf sections of Zea mays. Aust. J. Biol. Sci. 26, 1015-1034.

Peiter, E., Montanini, B., Gobert, A., Pedas, P., Husted, S., Maathuis, F. J. M., et al. (2007). A secretory pathway-localized cation diffusion facilitator confers plant manganese tolerance. Proc. Natl. Acad. Sci. U.S.A. 104, 8532-8537. doi: 10.1073/pnas.0609507104

Pittman, J. K. (2005). Managing the manganese: molecular mechanisms of manganese transport and homeostasis. New Phytol. 167, 733-742. doi: 10.1111/j.1469-8137.2005.01453.x

Pollard, A. J. (2000). Metal hyperaccumulation: a model system for coevolutionary studies. New Phytol. 146, 179-181. doi: 10.1046/j.14698137.2000.00651.x

Pollard, A. J., Dandridge, K. L., and Jhee, E. M. (2000). "Ecological genetics and the evolution of trace element hyperaccumulation in plants," in Phytoremediation of Contaminated Soil and Water, eds N. Terry and G. Banuelos (Boca Raton, FL: CRC Press LLC). 251-264.

Pollard, A. J., Powell, K. D., Harper, F. A., and Smith, J. A. (2002). The genetic basis of metal hyperaccumulation in plants. Crit. Rev. Plant Sci. 21, 539-566. doi: 10.1080/0735260291044359

Pollard, J. A., Stewart, H. L., and Roberson, C. B. (2009). Manganese Hyperaccumulation in Phytolacca americana L. from the Southeastern United States. Northeast. Nat. 16, 155-162. doi: 10.1656/ 045.016 .0513

Proctor, J., Phillips, C., Duff, G. K., Heany, A., and Robertson, F. M. (1989). Ecological studies on Gunung Silam, a small ultrabasic mountain in Sabah, Malaysia. II.
Some forest processes. J. Ecol. 77, 317-331. doi: 10.2307/2260752

Quiquampoix, H., Bacic, G., Loughman, B. C., and Ratcliffe, R. G. (1993a). Quantitative aspects of the 31P-NMR detection of manganese in plant tissues. J. Exp. Bot. 44, 1809-1818. doi: 10.1093/jxb/44.12.1809

Quiquampoix, H., Loughman, B. C., and Ratcliffe, R. G. (1993b). A 31P-NMR study of the uptake and compartmentation of manganese by maize roots. J. Exp. Bot. 44, 1819-1827. doi: 10.1093/jxb/44.12.1819

Reeves, R. D. (2005) "Hyperaccumulation of trace elements," in Phytoremediation of Metal-Contaminated Soils, (Proceedings of the NATO Advanced Study Institute, Trešt Castle, Czech Republic, 18-30 August 2002), ed J.-L. Morel GEaNG (Berlin: Springer).

Reeves, R. D., and Baker, A. J. M. (2000). "Metal-accumulating plants," in Phytoremediation of Toxic Metals: Using Plants to Clean up the Environment, eds I. Raskin and B. D. Ensley (New York, NY: John Wiley and Sons), 193-221.

Robinson, B. H., Lombi, E., Zhao, F. J., and McGrath, S. P. (2003). Uptake and distribution of nickel and other metals in the hyperaccumulator Berkheya coddii. New Phytol. 158, 279-285. doi: 10.1046/j.1469-8137.2003.00743.x

Roby, C., Bligny, R., Douce, R., Tu, S., and Pfeffer, P. (1988). Facilitated transport of $\mathrm{Mn} 2+$ in sycamore (Acer pseudoplatanus) cells and excised maize root tips. Biochem. J. 252, 401-408.

Sasaki, A., Yamaji, N., Yokosho, K., and FMa, J. (2012). Nramp5 is a major transporter responsible for manganese and cadmium uptake in rice. Plant Cell 24, 2155-2167. doi 10.1105/tpc.112.096925

Severne, B. C. (1974). Nickel accumulation by Hybanthus floribundus. Nature 248, 807-808. doi: $10.1038 / 248807 \mathrm{a} 0$

Smart, K. E., Smith, J. A. C., Kilburn, M. R., Martin, B. G. H., Hawes, C., and Grovenor, C. R. M (2010). High-resolution elemental localization in vacuolate plant cells by nanoscale secondary ion mass spectrometry. Plant J. 63, 870-879. doi: 10.1111/j.1365313X.2010.04279.x

StClair, S. B., and Lynch, J. P. (2005). Element accumulation patterns of deciduous and evergreen tree seedlings on acid soils: implications for sensitivity to manganese toxicity. Tree Physiol. 25, 85-92. doi: 10.1093/treephys/25.1.85

Temple-Smith, M. G., and Koen, T. B. (1982). Comparative response of poppy (Papavar somniferum L.) and eight crop and vegetable species to manganese excess in solution culture. J. Plant Nutr. 5, 1153-1169. doi: 10.1080/ 01904168209363048

Thomine, S., Wang, R., Ward, J. M., Crawford, N. M., and Schroeder, J. I. (2000). Cadmium and iron transport by members of a plant metal transporter family in Arabidopsis with homology to Nramp genes. Proc. Natl. Acad. Sci. U.S.A. 97, 4991-4996. doi: 10.1073/pnas.97.9.4991

Vázquez, M. D., Barceló, J., Poschenrieder, C., Mádico, J., Hatton, P., Baker, A. J. M., et al. (1992). Localisation of zinc and cadmium in Thlaspi caerulescens (Brassicaceae), a metallophyte that can hyperaccumulate both metals. J. Plant Physiol. 140, 350-355. doi: 10.1016/S01761617(11)81091-6

Wang, H., Tang, S., Liao, X., Cao, Q., Yang, A., and Wang, T. (2007). A new manganese-hyperaccumulator: Polygonum hydropiper L. Ecol. Environ. 2007, 830-834.

Weber, M., Harada, E., Vess, C., Roepenack-Lahaye, E., and Clemens, S. (2004). Comparative microarray analysis of Arabidopsis thaliana and Arabidopsis halleri roots identifies nicotinamine synthase, a zip transporter and other genes as potential metal hyperaccumulation factors. Plant J. 37, 269-281. doi: 10.1046/ j.1365-313X.2003.01960.x

Whiting, S. N., Reeves, R. D., Richards, D., Johnson, M. S., Cooke, J. A., Malisse, F., et al. (2004). Research priorities for conservation of metallophyte biodiversity and their potential for restoration and site remediation. Res. Ecol. 12, 106-116. doi: 10.1111/ j.1061-2971.2004.00367.x

Xue, S. G., Chen, Y. X., and Baker, A. J. M. (2005). Manganese uptake and accumulation by two populations of Phytolacca acinosa Roxb. (Phytolaccaceae). Water Air Soil Pollut. 160, 3-14. doi: 10.1007/ s11270-005-3349-0

Xue, S. G., Chen, Y. X., Reeves, R. D., Baker, A. J. M., Lin, Q., and Fernando, D. R. (2004). Manganese uptake and accumulation by the hyperaccumulator plant Phytolacca acinosa Roxb. (Phytolaccaceae). 
Environ. Pollut. 131, 393-399. doi: 10.1016/j.envpol.2004.03.011

$\mathrm{Xu}$, Shi, J., Chen, Y., Chen, X., Wang, H., and Perera, A. (2006a). Distribution and mobility of manganese in the hyperaccumulator plant Phytolacca acinosa Roxb. (Phytolaccaceae). Plant Soil 285, 323-331. doi: 10.1007/s11104-0069018-2

Xu, X. H., Shi, J. Y., Chen, Y. X., Xue, S. G., Wu, W. B., and Huang, Y. (2006b). An investigation of cellular manganese in hyperaccumulator plant Phytolacca acinosa Roxb. using SRXRF analysis. J. Environ. Sci. China 18, 746-751.

Xu, X., Shi, J., Chen, X., Chen, Y., and $\mathrm{Hu}, \mathrm{T}$. (2009). Chemical forms of manganese in the leaves of manganese hyperaccumulator Phytolacca acinosa Roxb. (Phytolaccaceae). Plant Soil 318, 197-204. doi: 10.1007/s11104-0089829-4

Yang, S. X., Deng, H., and Li, M. S. (2008). Manganese uptake and accumulation in a woody hyperaccumulator, Schima superba. Plant Soil Environ. 54, 441-446.
Conflict of Interest Statement: The authors declare that the research was conducted in the absence of any commercial or financial relationships that could be construed as a potential conflict of interest.

Received: 29 April 2013; accepted: 29 July 2013; published online: 20 August 2013. Citation: Fernando DR, Marshall A, Baker AJM and Mizuno T (2013) Microbeam methodologies as powerful tools in manganese hyperaccumulation research: present status and future directions. Front. Plant Sci. 4:319. doi: 10.3389/fpls.2013.00319
This article was submitted to Plant Physiology, a section of the journal Frontiers in Plant Science.

Copyright (๑) 2013 Fernando, Marshall, Baker and Mizuno. This is an openaccess article distributed under the terms of the Creative Commons Attribution License (CC BY). The use, distribution or reproduction in other forums is permitted, provided the original author(s) or licensor are credited and that the original publication in this journal is cited, in accordance with accepted academic practice. No use, distribution or reproduction is permitted which does not comply with these terms. 